\title{
Modifikasi Algoritme Bellman-Ford Untuk Pencarian Rute Terpendek Berdasarkan Kondisi Jalan
}

\author{
Modified Bellman-Ford Algorithm for Finding the Shortest Path Based on Road \\ Conditions \\ Yaddarabullah $\left.{ }^{*}\right)$
}

Program Studi Teknik Informatika, Fakultas Industri Kreatif dan Telematika, Universitas Trilogi Jl. TMP Kalibata No.1, Jakarta, Indonesia 12760

Cara sitasi: Y. Yaddarabullah, "Modifikasi Algoritme Bellman-Ford Untuk Pencarian Rute Terpendek Berbasis Kondisi Jalan," Jurnal Teknologi dan Sistem Komputer, vol. 7 no. 3, pp. 109-115, 2019. doi: 10.14710/jtsiskom.7.2.2019.109-115, [Online].

\begin{abstract}
The application of the Bellman-ford algorithm for finding the shortest path both weighted and unweighted graph has a weakness in determining the shortest path based on road conditions. This study modified the Bellman-Ford algorithm by adding the Technique for Order of Preference by Similarity to the Ideal Solution method to provide alternative road assessments based on its condition criteria including road density, road width, travel time, and distance. This modified Bellman-Ford has better performance in finding the alternative shortest path by choosing a road with smoother conditions, even though distance and travel time increase.
\end{abstract}

Key Word - modified Bellman-Ford algorithm; shortest path finding; TOPSIS

Abstrak - Penerapan algoritme Bellman-Ford untuk
pencarian lintasan terpendek dalam suatu graf
berbobot atau tidak berbobot mempunyai kelemahan
dalam menentukan rute terpendek berdasarkan
faktor-faktor kondisi jalan. Penelitian ini mengkaji
modifikasi algoritme Bellman-Ford dengan
menambahkan metode Technique for Order of
Preference by Similarity to Ideal Solution untuk
memberikan penilaian alternatif jalan berdasarkan
kriteria kondisi jalan meliputi tingkat kepadatan jalan,
lebar jalan, waktu tempuh, dan jarak. Bellman-Ford
yang dimodifikasi ini mempunyai kinerja yang lebih
baik dalam menemukan jalur terpendek alternatif
dengan memilih jalan dengan kondisi lebih lancar,
walaupun jarak dan waktu tempuh bertambah.

Kata Kunci - modifikasi Bellman-Ford; pencarian rute terpendek; TOPSIS; kepadatan jalan

\section{Pendahuluan}

Algoritme Bellman-Ford dapat digunakan untuk menentukan rute terpendek, yaitu dengan menghitung semua nilai jarak terpendek dari titik asal ke titik tujuan

\footnotetext{
${ }^{*}$ Penulis korespondensi (Yaddarabullah)
}

Email: yaddarabullah@trilogi.ac.id pada suatu graf berbobot atau graf tidak berbobot. Perhitungan yang digunakan pada algoritme ini adalah berdasarkan nilai jarak yang diambil dari bobot sisi antara dua titik dan persimpangan dari satu titik ke titik yang lain dan dapat digunakan untuk menghitung pada sisi yang bernilai negatif [1]. Penelitian yang menggunakan Bellman-Ford dalam menentukan rute terpendek sudah banyak dilakukan, di antaranya untuk menentukan rute terdekat dalam pendistribusian barang [2], mencari rute terpendek menuju ke tempat makan [3], mencari rute terdekat bagi pemadam kebakaran menuju ke lokasi kebakaran [4], dan mencari rute terpendek menuju museum terdekat [5].

Penentuan rute terpendek pada penelitian yang menggunakan algoritme Bellman-Ford tersebut di atas belum dapat menangani permasalahan berdasarkan kondisi jalan, salah satunya adalah jika pada dua titik memiliki beberapa pilihan jalan alternatif. Dalam memilih jalan alternatif tersebut dipengaruhi oleh kondisi jalan, seperti tingkat kepadatan jalan yang dipengaruhi oleh volume dan kecepatan kendaraan [6].

Penelitian ini mengkaji modifikasi terhadap algoritme Bellman-Ford, yaitu dengan menambahkan proses penentuan jalan alternatif jika ditemukan pada dua titik yang memiliki beberapa pilihan jalan alternatif. Metode Technique for Order of Preference by Similarity to Ideal Solution (TOPSIS) digunakan untuk mengambil keputusan terhadap jalan alternatif yang dipilih berdasarkan multikriteria dan bobot preferensi yang telah ditentukan [7]. Kriteria dan bobot preferensi yang digunakan pada metode TOPSIS dalam pemilihan jalan alternatif, yaitu tingkat kepadatan jalan menurut [8], lebar jalan atau penampang badan jalan menurut [9], waktu tempuh antara titik, dan jarak. Proses dan hasil dari algoritme Bellman-Ford dioptimalkan dalam pencarian rute terpendek yang didasari oleh faktor kondisi jalan.

\section{Metode Penelitian}

Algoritme Bellman-Ford dalam kajian ini digunakan untuk menghitung jarak terpendek pada sebuah graf 
berbobot dengan mengawali dari satu titik awal ke titik tujuan [10]. Algoritme Bellman-Ford menggunakan fungsi $\mathrm{O}(\mathrm{V}, \mathrm{E})$, dimana $\mathrm{V}$ menyatakan jarak dan $\mathrm{E}$ menyatakan sisi. Dalam hal ini, bobot pada sisi ekuivalen sama dengan jarak. Algoritme ini menggunakan $\mathrm{d}[\mathrm{U}]$ sebagai titik pertama dengan jarak $\mathrm{d}[\mathrm{U}, \mathrm{V}]$ yaitu dari titik U sebagai titik asal dan titik V sebagai titik sebelahnya [2] (Persamaan 1).

$$
M[i, v]=\min \left(M[i-1, v],\left(M\left[i+1+C_{v n}\right]\right)\right)
$$

Nilai rute terpendek diperoleh berdasarkan hasil minimum perhitungan yang dimulai dari titik awal sampai ke titik akhir. Proses dalam algoritme ini diawali dengan menentukan titik awal dan melakukan penandaan simpul, kemudian memberikan nilai 0 untuk titik awal dan nilai tidak terhingga untuk titik lainnya. Penandaan simpul pada graf berbobot ditunjukkan dalam Gambar 1.

Proses selanjutnya adalah melakukan iterasi terhadap semua titik yang ada pada graf, dimulai dari titik awal U untuk mendapatkan nilai jarak pada titik di sebelahnya V. Pengecekan dilakukan untuk semua sisi UV. Jika nilai jarak pada V lebih besar dari nilai jarak U+bobot sisi UV, maka nilai jarak $\mathrm{V}$ diisi dengan U+bobot sisi UV. Langkah ini dilakukan sampai semua titik terkunjungi. Hasil akhir didapatkan setelah proses iterasi dilakukan ke semua titik, yaitu nilai dan deretan rute terpendek.

Modifikasi algoritme Bellman-Ford dilakukan dengan menentukan jalan alternatif dari dua titik yang memiliki beberapa pilihan jalan alternatif dengan menerapkan metode TOPSIS. Pada proses metode TOPSIS dalam menentukan jalan alternatif menggunakan empat kriteria, yaitu kepadatan jalan berdasarkan volume kendaraan dan kecepatan kendaraan, lebar jalan dalam satuan meter, waktu tempuh dalam satuan menit, dan jarak dalam satuan km. Arus lalu lintas yang lancar dengan kecepatan tinggi dan volume rendah mendapatkan prioritas tinggi, sedangkan arus padat dengan kecepatan rendah. Bobot untuk setiap kriteria yang digunakan ditunjukkan dalam Tabel 1 Tabel 4.

Pada kriteria tingkat kepadatan jalan, bobot digunakan sebagai nilai yang diproses dalam metode TOPSIS. Nilai dari kriteria lebar jalan, waktu tempuh dan jarak, yaitu dari data masukan sesuai parameter dikalikan dengan masing-masing bobot. Hasil penilaian ini diproses dalam meotde TOPSIS. Prosedur dalam metode TOPSIS terdiri dari langkah-langkah yang dinyatakan dalam Algoritme 1. Modifikasi pada algoritme Bellman-Ford dilakukan dengan menyisipkan proses metode TOPSIS di dalamnya. Hasil dari modifikasi algoritme Bellman-Ford dinyatakan dalam Algoritme 2.

Pengujian terhadap hasil modifikasi algoritme Bellman-Ford dilakukan dengan eksperimen terhadap satu contoh studi kasus. Hasil modifikasi Bellman-Ford ini dibandingkan dengan proses algoritme Bellman-Ford

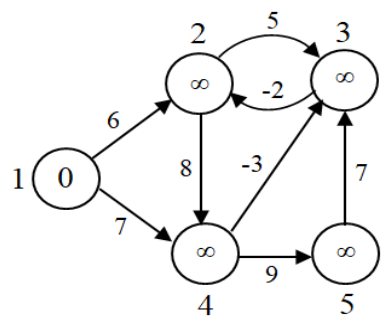

Gambar 1. Penandaan simpul pada graf

Tabel 1. Kriteria tingkat kepadatan jalan (C1)

\begin{tabular}{cllc}
\hline No & \multicolumn{1}{c}{ Parameter } & Keterangan & Bobot \\
\hline 1 & $\begin{array}{l}\text { Arus lancar, kecepatan } \\
\text { tinggi dan volume rendah }\end{array}$ & Sangat Stabil & 4 \\
2 & $\begin{array}{l}\text { Arus stabil, kecepatan } \\
\text { lambat }\end{array}$ & Stabil & 3 \\
3 & $\begin{array}{l}\text { Arus tidak stabil kecepatan } \\
\text { terkadang terhenti }\end{array}$ & Macet & 2 \\
4 & $\begin{array}{l}\text { Arus padat, kecepatan } \\
\text { rendah, volume diatas } \\
\text { kapasitas, antrian panjang }\end{array}$ & $\begin{array}{l}\text { Sangat } \\
\text { Macet }\end{array}$ & 1 \\
\hline
\end{tabular}

Tabel 2. Kriteria lebar jalan (C2)

\begin{tabular}{cllc}
\hline No & \multicolumn{1}{c}{ Parameter } & Keterangan & Bobot \\
\hline 1 & Kurang dari 2 meter & Sempit & 1 \\
2 & Antara 3 sampai 4 meter & Kurang lebar & 2 \\
3 & Antara 5 sampai 6 meter & Lebar & 3 \\
4 & Lebih dari 7 menter & Sangat lebar & 4 \\
\hline
\end{tabular}

Tabel 3. Kriteria waktu tempuh (C3)

\begin{tabular}{cllc}
\hline No & \multicolumn{1}{c}{ Parameter } & Keterangan & Bobot \\
\hline 1 & $\begin{array}{l}\text { Waktu tempuh kurang dari } \\
\text { 30 menit }\end{array}$ & Sangat cepat & 4 \\
2 & $\begin{array}{l}\text { Waktu tempuh antara 30 } \\
\text { sampai 60 menit }\end{array}$ & Cukup cepat & 3 \\
3 & $\begin{array}{l}\text { Waktu tempuh antara 60 } \\
\text { sampai 120 menit }\end{array}$ & Lambat & 2 \\
4 & $\begin{array}{l}\text { Waktu tempuh lebih dari } \\
\text { 120 menit }\end{array}$ & $\begin{array}{l}\text { Sangat } \\
\text { lambat }\end{array}$ & 1 \\
\hline
\end{tabular}

Tabel 4. Kriteria jarak (C4)

\begin{tabular}{cllc}
\hline No & \multicolumn{1}{c}{ Parameter } & Keterangan & Bobot \\
\hline 1 & Jarak kurang dari $1 \mathrm{~km}$ & Sangat dekat & 4 \\
2 & Jarak antara $1 \mathrm{~km}-2 \mathrm{~km}$ & Dekat & 3 \\
3 & Jarak antara $2 \mathrm{~km} \mathrm{-} \mathrm{3} \mathrm{km}$ & Jauh & 2 \\
4 & Jarak lebih dari $3 \mathrm{~km}$ & Sangat jauh & 1 \\
\hline
\end{tabular}

tanpa modifikasi untuk mengetahui nilai jarak rute dan performa.

\section{HASil dan PEMbahasan}

Pengujian hasil modifikasi algoritme Bellman-Ford menggunakan sebuah studi kasus. Studi kasus yang dijadikan untuk pengujian dari modifikasi algoritme Bellman-Ford ini mengambil sebagian peta Jabodetabek 


\section{Algoritme 1. Tahapan metode TOPSIS}

1: Menentukan keputusan dalam matriks ternormalisasi berdasarkan kriteria dengan Persamaan 2. Nilai $\mathrm{r}_{\mathrm{ij}}$ adalah matrik ternormalisasi, $\mathrm{x}_{\mathrm{ij}}$ adalah nilai pada baris ke i (alternatif) dan kolom ke j (kriteria).

$$
r_{i j}=\frac{x_{i j}}{\sqrt{\sum_{i=1}^{m} x_{i j}^{2}}}
$$

2: Menentukan matriks keputusan ternormalisasi dengan bobot preferensi dari setiap kriteria yang diberikan dengan Persamaan 3. Nilai $w$ adalah bobot preferensi, $\mathrm{y}_{i j}$ adalah matrik ternormalisasi terbobot dan $r_{i j}$ adalah nilai matrik ternormalisasi.

$$
y_{i j}=w_{i} \cdot r_{i j}
$$

3: Menghitung matriks solusi ideal positif $\left(\mathrm{A}^{+}\right)$dan matriks solusi ideal negatif $\left(\mathrm{A}^{-}\right)$dari matriks keputusan ternormalisasi terbobot. Hal ini dilakukan untuk mendapatkan nilai maksimum dan nilai minimum (Persamaan 4). Nilai $y_{j}^{+}=\max _{i} y_{i j}$ jika j adalah atribut keuntungan dan $y_{j}^{+}=\min _{i} y_{i j}$ jika $\mathrm{j}$ atribut biaya. Nilai $\overline{y_{j}}=\min _{i} y_{i j}$ jika $\mathrm{j}$ adalah atribut keuntungan dan $y_{j}^{-}=\max _{i} y_{i j}$ jika j atribut biaya.

$$
A^{+}=\left(y_{1}^{+}, y_{2}, \ldots y_{m}\right), A^{-}=\left(y_{1}^{-}, y_{2}, \ldots y_{m}\right)
$$

4: $\quad$ Menghitung jarak antara alternatif $A_{i}$ dengan solusi ideal positif $D_{i}^{+}$dan solusi ideal negatif $D_{i}^{-}$ (Persamaan 5).

$$
D_{i}^{+}=\sqrt{\sum_{j=1}^{n}\left(y_{i}^{+}-y_{i j}\right)^{2}}, D_{i}^{-}=\sqrt{\sum_{j=1}^{n}\left(y_{i j}-y_{i}^{-}\right)^{2}}
$$

5: Menentukan nilai preferensi untuk setiap nilai preferensi, yaitu mendapatkan nilai kedekatan dari setiap alternatif dengan Persamaan 6. $V_{i}$ adalah nilai preferensi, $D_{i}^{-}$adalah jarak antar solusi ideal negatif dan $D_{i}^{+}$adalah jarak antar solusi ideal positif.

$$
V_{i}=\frac{D_{i}^{-}}{D_{i}^{-}+D_{i}^{+}}
$$

6: Merangking alternatif berdasarkan nilai preferensi $\left(V_{i}\right)$. Alternatif terbaik diambil adalah salah satu yang berjarak paling pendek terhadap solusi ideal positif dan berjarak paling jauh dengan solusi ideal negatif atau alternatif yang memiliki nilai preferensi paling tinggi.
Algoritme 2. Modifikasi Bellman-Ford untuk pencarian rute terpendek.

1: Menentukan titik awal dan titik tujuan.

2: Mendaftarkan semua titik dan sisi dari graf.

3: Memberikan nilai 0 pada titik asal dan nilai tidak terhingga untuk titik lainnya.

4: Melakukan iterasi terhadap semua titik dimulai dari titik awal. Dalam menentukan nilai jarak dari semua titik yang berhubungan, jika nilai jarak V lebih besar dari nilai jarak U+bobot sisi UV maka nilai jarak V diisi dengan nilai karak U+bobot sisi UV. Pada saat iterasi dilakukan pengecekan pada tahapan nomor 5 dan 6.

5: Jika dari satu titik ke titik lain terdapat beberapa jalan alternatif, maka alternatif dipilih menggunakan metode TOPSIS. Nilai hasil perangkingan dari metode TOPSIS menjadi nilai bobot sisi UV pada kedua titik. Perhitungan nilai jarak UV berdasarkan nilai bobot sisi UV.

6: Jika dari satu titik ke titik lain hanya ada satu pilihan jalan, maka nilai bobot sisi UV akan dihitung dengan rata-rata rute terbobot dengan Persamaan 7. Nilai UV adalah bobot sisi pada V yaitu jumlah dari akar hasil perkalian nilai input setiap kriteria $\left(\mathrm{N}_{\mathrm{i}}\right)$ dengan nilai bobot setiap kriteria dalam rute tersebut $\left(\mathrm{W}_{\mathrm{i}}\right)$ dan bobot preferensi $\left(\mathrm{C}_{\mathrm{i}}\right)$, kemudian dibagi dengan nilai maksimal dari bobot setiap kriteria $\left(\max \left(\mathrm{W}_{\mathrm{i}}\right)\right)$ dikali nilai bobot preferensi $\left(\mathrm{C}_{\mathrm{i}}\right)$. Nilai $\mathrm{V}$ akan dihitung berdasarkan nilai bobot UV yang telah didapatkan.

$$
U V=\frac{\sum_{i=1}^{n} \sqrt{N_{i} \times W_{i} \times C_{i}}}{\sum_{i=1}^{n} \max \left(W_{i}\right) \times C_{i}}
$$

7: Menentukan rute terpendek berdasarkan nilai terkecil dari setiap titik dari titik awal sampai ke titik akhir.

yang bersumber dari Google Maps dengan beberapa titik terhubung. Ada lima titik yang dijadikan sebagai simpul dengan berbagai rute jalan yang menghubungkan antar titik. Peta dan sebaran titik yang digunakan ditunjukkan dalam Gambar 2. Titik A menunjukkan Kalibata, B Cawang, C Cawang Otista, D Dewi Sartika, dan E Kalimalang.

Data lebar jalan berdasarkan data sekunder yang diperoleh melalui http://data.jakarta.go.id/dataset/datadaftar-jalan-kolektor-di-dki-jakarta dengan mengambil pada dataset jalan kolektor sekunder di Provinsi DKI Jakarta. Data waktu tempuh, jarak dan pilihan rute antar kedua titik didapatkan berdasarkan penelusuran melalui Google Maps, yaitu dengan membuat direction dari satu titik ke titik lain. Data diambil pada kondisi pagi hari. Berdasarkan titik yang saling terhubung ada beberapa pilihan rute yang diambil berdasarkan jalan yang dilintasi oleh kendaraan. Bobot preferensi untuk setiap kriteria adalah $(\mathrm{C} 1, \mathrm{C} 2, \mathrm{C} 3, \mathrm{C} 4)=(4,2,3,1)$. 


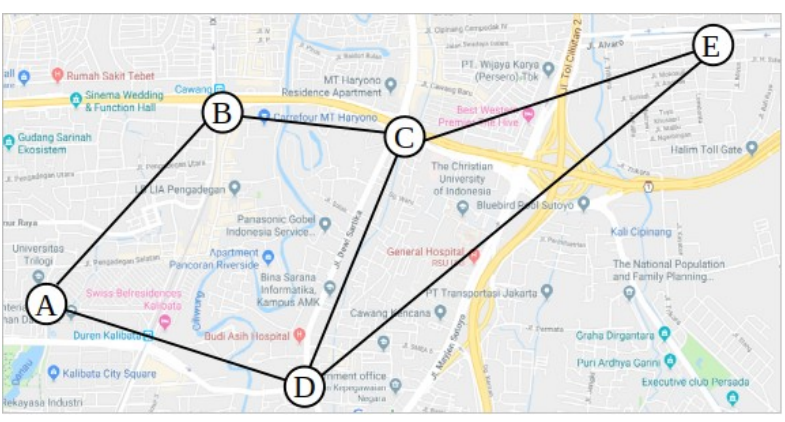

Gambar 2. Penampang peta untuk pengujian

Dalam perhitungan TOPSIS untuk kriteria pertama (C1), diambil nilai dari bobot yang telah ditentukan berdasarkan sumber data. Untuk kriteria kedua sampai keempat, diambil berdasarkan input dari keterangan setiap titik yang dikalikan dengan masing-masing bobot pada setiap kriteria. Keterangan dari setiap titik dan kriteria yang diuji ditunjukkan dalam Tabel 5.

Proses pengujian pencarian rute terpendek dimulai dari titik awal A menuju ke titik akhir F. Input data kriteria tingkat kepadatan jalan (C1) menggunakan simulasi. Iterasi pertama yaitu dari titik A-B dengan C1 untuk rute pertama "stabil" dan rute kedua "macet". Titik A-D dengan C1 "sangat macet". Jalan alternatif dari titik A-B dipilih menggunakan metode TOPSIS. Untuk titik A-D hanya ada satu jalan sehingga dinilai rerata rute dari nilai keempat kriteria menggunakan Persamaan 8 sebagai berikut:

$$
\begin{aligned}
U V & =\frac{(\sqrt{1 \times 1 \times 4})+(\sqrt{7 \times 4 \times 2})+(\sqrt{26 \times 4 \times 3})+(\sqrt{2,1 \times 2 \times 1})}{(4 \times 4)+(4 \times 2)+(4 \times 3)+(4 \times 1)} \\
& =0,73
\end{aligned}
$$

Matrik yang dihasilkan pada saat diproses dalam metode TOPSIS dinyatakan sebagai berikut:

$$
\begin{gathered}
x_{i j}=\left[\begin{array}{llll}
3 & 28 & 28 & 5 \\
2 & 28 & 36 & 5,2
\end{array}\right] \\
r_{i j}=\left[\begin{array}{llll}
0,83 & 0,71 & 0,61 & 0,69 \\
0,55 & 0,71 & 0,79 & 0,72
\end{array}\right] \\
y_{i j}=\left[\begin{array}{llll}
0,83 & 0,71 & 0,61 & 0,69 \\
0,55 & 0,71 & 0,79 & 0,72
\end{array}\right] \\
A^{+}=\left(\begin{array}{llll}
3,22 & 1,41 & 2,37 & 0,72
\end{array}\right) \\
A^{-}=\left(\begin{array}{llll}
2,22 & 1,41 & 1,84 & 0,69
\end{array}\right) \\
D_{1}^{+}=0,54, D_{2}^{+}=1, D_{1}^{-}=1,11, D_{2}^{-}=0,87 \\
V_{1}=0,67, V_{2}=0,46
\end{gathered}
$$

\begin{tabular}{|c|c|c|c|c|c|}
\hline Titik & C1 & $\mathrm{C} 2$ & C3 & C4 & Jalan \\
\hline \multirow[t]{2}{*}{ A-B } & Stabil & 7 & 7 & 2.5 & Pengadegan Selatan \\
\hline & Macet & 7 & 9 & 2.6 & Pengadegan Utara V \\
\hline $\mathrm{B}-\mathrm{C}$ & Macet & 8.7 & 10 & 1.1 & Letjen MT Haryono \\
\hline \multirow[t]{2}{*}{ C-E } & Macet & 8 & 26 & 2.2 & Cawang Baru \\
\hline & $\begin{array}{l}\text { Sangat } \\
\text { Macet }\end{array}$ & 8 & 5 & 2.1 & DI Panjaitan \\
\hline A-D & $\begin{array}{l}\text { Sangat } \\
\text { Macet }\end{array}$ & 7 & 26 & 2.1 & Raya Kalibata \\
\hline \multirow[t]{3}{*}{ D-E } & Stabil & 12 & 58 & 4.6 & $\begin{array}{l}\text { Dewi Sartika, Cawang, } \\
\text { Letjen MT Haryono, } \\
\text { DI Panjaitan }\end{array}$ \\
\hline & Macet & 10 & 46 & 3.8 & $\begin{array}{l}\text { Dewi Sartika, UKI } \\
\text { Cawang, DI Panjaitan }\end{array}$ \\
\hline & Macet & 10 & 53 & 4.3 & $\begin{array}{l}\text { Mayjen Sutoyo, } \\
\text { Inspeksi Kalimalang }\end{array}$ \\
\hline $\mathrm{D}-\mathrm{C}$ & Macet & 12 & 20 & 1.6 & Dewi Sartika \\
\hline
\end{tabular}

Hasil dari metode TOPSIS menunjukkan nilai terbesar adalah $\mathrm{V}_{1}$, yaitu rute pertama melalui $\mathrm{Jl}$. Pengadegan Selatan. Hasil penilaian bobot UV dan nilai jarak V dari iterasi pertama ditunjukkan pada Tabel 6 . Pada iterasi pertama diketahui nilai $\mathrm{V}$ yang terkecil adalah titik A-B dengan nilai 0,67, sedangkan nilai dari titik A-D adalah 0,73. Dengan demikian, pilihan rute
Tabel 5. Keterangan titik dan kriteria uji

Tabel 6. Penilaian UV dan V di iterasi pertama

\begin{tabular}{cccl}
\hline Titik & Bobot UV & Nilai V & \multicolumn{1}{c}{ Jalan } \\
\hline A-B & 0,67 & 0,67 & Pengadegan Selatan \\
A-D & 0,73 & 0,73 & Raya Kalibata \\
\hline
\end{tabular}

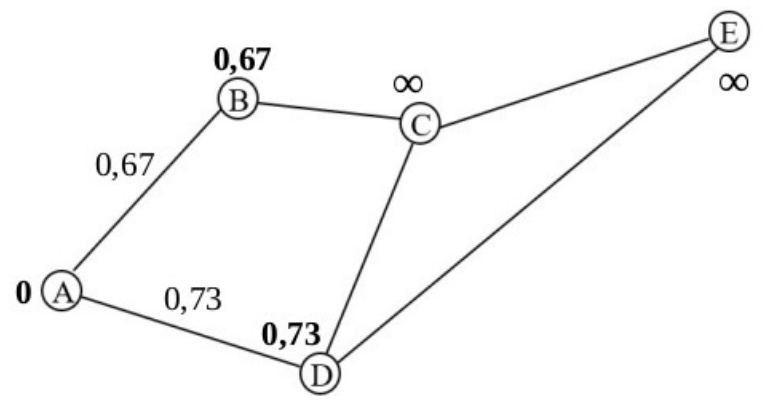

Gambar 3. Penampang graf hasil iterasi pertama

pada iterasi pertama adalah titik A-B. Graf hasil dari iterasi pertama ditunjukkan dalam Gambar 3.

Pada iterasi kedua, yaitu dari titik B-C dengan C1 “macet”, titik D-C dengan C1 "macet”. Titik B-C dan titik D-C hanya terdapat satu pilihan jalan, maka dinilai rerata rute. Titik D-E terdapat tiga pilihan jalan alternatif dimana C1 untuk rute pertama "stabil", C1 untuk rute kedua "macet”, dan C1 untuk rute ketiga "macet". Pilihan jalan alternatif untuk titik D-E ditentukan dengan metode TOPSIS. Berikut adalah perhitungan matriks yang dihasilkan pada saat diproses dalam metode TOPSIS.

$$
\begin{gathered}
x_{i j}=\left[\begin{array}{llll}
3 & 48 & 174 & 4,6 \\
2 & 40 & 138 & 3,8 \\
2 & 40 & 212 & 4,8
\end{array}\right] \\
r_{i j}=\left[\begin{array}{llll}
0,83 & 0,77 & 0,78 & 0,77 \\
0,55 & 0,64 & 0,62 & 0,64 \\
0,55 & 0,64 & 0,95 & 0,80
\end{array}\right]
\end{gathered}
$$




$$
\begin{aligned}
y_{i j} & =\left[\begin{array}{llll}
3,33 & 1,54 & 2,35 & 0,77 \\
2,22 & 1,28 & 1,86 & 0,64 \\
2,22 & 1,28 & 2,86 & 0,80
\end{array}\right] \\
A^{+} & =\left(\begin{array}{llll}
3,33 & 1,54 & 2,86 & 0,80
\end{array}\right) \\
A^{-} & =\left(\begin{array}{llll}
2,22 & 1,28 & 1,86 & 0,64
\end{array}\right) \\
D_{1}^{+} & =051, D_{2}^{+}=1,52, D_{3}^{+}=1,14 \\
D_{1}^{-} & =1,24, D_{2}^{-}=016, D_{3}^{-}=1,19 \\
V_{1} & =0,71, \quad V_{2}=0,10, V_{3}=0,51
\end{aligned}
$$

Hasil dari metode TOPSIS menunjukkan nilai terbesar adalah $\mathrm{V}_{1}$, yaitu jalan pertama melalui Jl. Dewi Sartika - Jl. Cawang - Jl. MT Haryono - Jl. DI. Panjaitan. Hasil perhitungan nilai bobot UV dan V dari iterasi kedua ditunjukkan pada Tabel 7.

Pada titik D-C didapatkan rerata rute sebesar 0,78 yang dijadikan sebagai bobot $\mathrm{U}$, sehingga nilai $\mathrm{V}$-nya adalah 1,51. Karena nilai $\mathrm{V}$ pada titik D-C lebih besar dari titik B-C, maka pilihan rute ke $\mathrm{C}$ hanya diambil dari titik B. Hasil dari iterasi kedua dihitung dengan hasil dari iterasi pertama yaitu pada titik A-B-C dengan nilai 1,3 dan titik A-D-E dengan nilai 1,44. Dengan demikian, pada iterasi kedua diambil rute dengan titik A-B-C. Hasil dari iterasi kedua memperbaharui nilai dari titik pada graf seperti ditunjukkan dalam Gambar 4.

Iterasi ketiga yaitu dari titik C-E. Titik C-E ini mempunyai dua pilihan jalan alternatif yaitu untuk C1 dari jalan pertama adalah "macet” dan C1 jalan kedua adalah "sangat macet”. Pilihan jalan alternatif untuk titik C-E ditentukan dengan metode TOPSIS. Berikut adalah perhitungan matriks yang dihasilkan pada saat diproses dalam metode TOPSIS.

$$
\begin{gathered}
x_{i j}=\left[\begin{array}{llll}
2 & 32 & 104 & 4,4 \\
2 & 32 & 20 & 4,2
\end{array}\right] \\
r_{i j}=\left[\begin{array}{llll}
0,89 & 0,71 & 0,98 & 0,72 \\
0,45 & 0,71 & 0,19 & 0,69
\end{array}\right] \\
y_{i j}=\left[\begin{array}{llll}
3,58 & 1,41 & 2,95 & 0,72 \\
1,79 & 1,41 & 0,57 & 0,69
\end{array}\right] \\
A^{+}=\left(\begin{array}{llll}
3,58 & 1,41 & 2,95 & 0,72
\end{array}\right) \\
A^{-}=\left(\begin{array}{llll}
1,79 & 1,41 & 0,57 & 0,69
\end{array}\right) \\
D_{1}^{+}=0,01, D_{2}^{+}=2,98, D_{1}^{-}=2,97, D_{2}^{-}=0,69 \\
V_{1}=1, V_{2}=0,19
\end{gathered}
$$

Hasil dari metode TOPSIS menunjukkan nilai terbesar adalah $\mathrm{V}_{1}$, yaitu jalan pertama melalui $\mathrm{Jl}$. Cawang Baru atau titik C-E dengan bobot UV sebesar 1 dan nilai $\mathrm{V}$ sebesar 2,3. Hasil dari iterasi ketiga dihitung dengan iterasi kedua yaitu titik A-B-C-E dengan nilai 2,3 dan titik A-D-E dengan nilai 1,44. Hasil dari iterasi ketiga memperbaharui nilai dari titik pada graf seperti ditunjukkan Gambar 5. Dengan demikian, hasil akhir dari pencarian lintasan terpendek
Tabel 7. Penilaian UV dan V di iterasi kedua

\begin{tabular}{cccl} 
Titik & Bobot UV & Nilai V & \multicolumn{1}{c}{ Jalan } \\
\hline B-C & 0,63 & 1,3 & Letjen MT Haryono \\
D-C & 0,78 & 1,51 & Dewi Sartika \\
D-E & 0,71 & 1,44 & Dewi Sartika, Cawang, \\
& & & MT Haryono, \\
& & & DI Panjaitan \\
\hline
\end{tabular}

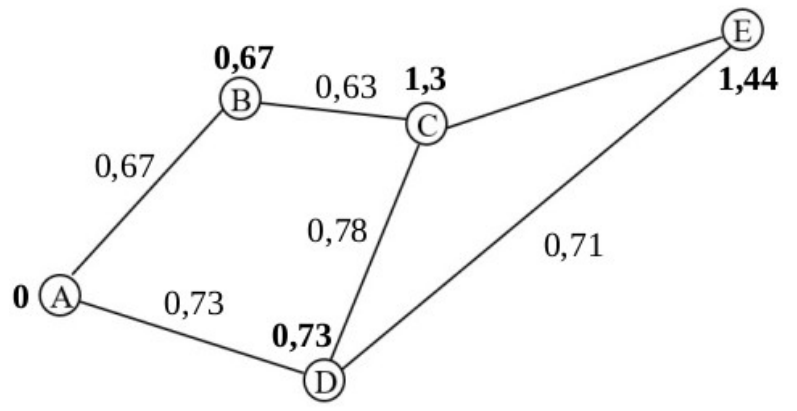

Gambar 4. Penampang graf hasil iterasi kedua

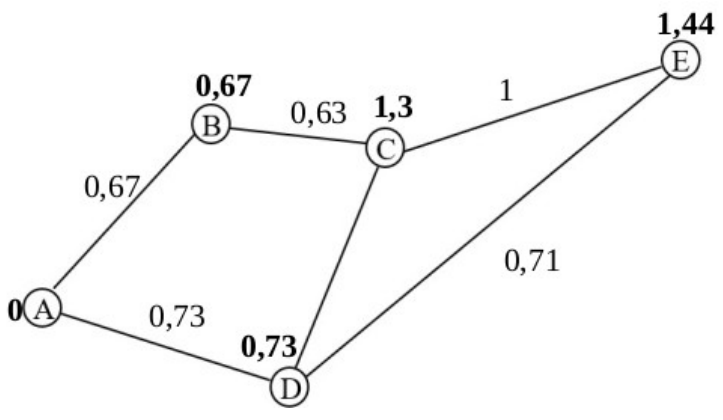

Gambar 5. Penampang graf hasil iterasi ketiga

dari titik awal A ke titik akhir E adalah melalui titik AD-E dengan rute melalui Jl. Raya Kalibata - Jl. Dewi Sartika - Jl. Cawang - Jl. MT Haryono - Jl. DI. Panjaitan. Nilai rute dari titik A-D-E adalah sebesar 1,44 dengan jarak tempuh 6,7 km, kondisi jalan stabil dan waktu tempuh sebesar 84 menit.

Hasil optimasi Bellman-Ford ini dibandingkan dengan proses Bellman-Ford yang tidak dimodifikasi dengan peta dan sebaran titik yang sama. Pada kasus ini, dipilih jalan berdasarkan tingkat preferensi paling tinggi di antara empat kriteria, yaitu kepadatan jalan (C1). Jika antara dua titik terdapat beberapa pilihan rute jalan, maka rute jalan dipilih berdasarkan rute yang paling sering digunakan dan diketahui oleh pengguna jalan. Keterangan titik yang digunakan ditunjukkan dalam Tabel 8.

Hasil dari proses algoritme Bellman-Ford terhadap titik tersebut menentukan rute terpendek yang dimulai dari titik A menuju titik E. Iterasi pertama menunjukkan nilai dari titik $\mathrm{B}$ adalah 0,69 dan titik $\mathrm{D}$ adalah 0,73 menjadi seperti graf dalam Gambar 6.

Iterasi kedua menentukan nilai titik $\mathrm{C}$ dan E. Pada saat perhitungan dari titik B ke C didapatkan nilai sebesar 0,63 sehingga nilai titik $C$ dari rute A-B sebesar 1,32, sedangkan dari titik $\mathrm{D}$ ke $\mathrm{C}$ didapatkan nilai sebesar 0,78 sehingga nilai titik $C$ dari rute A-D sebesar 
1,51. Karena nilai titik $\mathrm{C}$ dari rute A-B lebih kecil dari rute $\mathrm{A}-\mathrm{D}$, maka ditentukan nilai titik $\mathrm{C}$ adalah 1,32 dan rute yang dipilih adalah A-B-C. Perhitungan dari titik D ke $\mathrm{E}$ adalah sebesar 0,92 sehingga didapatkan nilai titik E sebesar 1,65 sehingga sementara dipilih rute A-D-E. Hasil dari iterasi kedua ditunjukkan dalam Gambar 7.

Iterasi ketiga menentukan nilai dari titik E. Pada proses ini, diperoleh nilai dari titik $\mathrm{C}$ ke E sebesar 0,49 sehingga titik $\mathrm{E}$ dari rute $\mathrm{A}-\mathrm{B}-\mathrm{C}$ sebesar 1,81 . Karena nilai titik $\mathrm{E}$ dari rute A-D lebih besar dari rute A-B-C, maka ditentukan nilai titik $\mathrm{E}$ adalah 1,65 dengan pilihan rute terpendek adalah A-D-E. Gambar 8 adalah graf hasil dari iterasi ketiga.

Dari hasil penentuan rute terpendek dengan algoritme Bellman-Ford tanpa modifikasi, jalan yang ditempuh adalah Jl. Raya Kalibata - Jl. Meyjen Sutoyo - Jl. Inspeksi Kalimalang. Nilai rute dari titik A-D-E adalah sebesar 1,65 dengan jarak yang ditempuh sebesar 6,4 km, kondisi jalan macet dan waktu tempuh sebesar 79 menit.

Modifikasi algoritme Bellman-Ford dengan proses TOPSIS pada saat pencarian rute terpendek menghasilkan nilai rute yang lebih rendah dibandingkan dengan Bellman-Ford yang tidak dimodifikasi seperti halnya dalam [1]-[5] dan [10], namun nilai jarak dan waktu tempuh yang lebih tinggi dari modifikasi algoritme Bellman-Ford (Tabel 9). Hal ini terjadi karena ada proses pemilihan jalan alternatif dari titik yang memiliki lebih dari satu jalan sehingga jalan alternatif yang dipilih menyebabkan nilai jarak menjadi lebih besar dibandingkan dengan algoritme Bellman-Ford yang tidak dimodifikasi.

Hasil uji dan perbandingan tersebut juga memperlihatkan bahwa rute yang ditempuh dari hasil modifikasi algoritme Bellman-Ford memiliki kriteria tingkat kepadatan jalan yang stabil, sedangkan hasil dari algoritme Bellman-Ford biasa memiliki kriteria tingkat kepadatan jalan macet. Hal ini menandakan bahwa dengan modifikasi algoritme Bellman-Ford dapat meningkatkan kinerja pada saat pemilihan jalan alternatif menggunakan TOPSIS dengan kriteria stabil. Berbeda dengan algoritme Bellman-Ford tanpa modifikasi, modifikasi ini dapat mengatasi jika antara dua titik simpul jalan memiliki berbagai jalan alternatif sesuai yang diidentifikasikan dalam [6]. TOPSIS ini dapat diterapkan untuk memilih rute jalan berdasarkan kriteria kepadatan dan lebar jalan [8], [9].

Pengembangan lebih lanjut dapat menyertakan sumber masukan data kriteria kondisi jalan yang bisa didapatkan secara langsung (realtime) dari rekaman CCTV atau hasil dari rekognisi citra jalan, analisis data time series dan analisis data VCR [6]. Hal ini dilakukan agar dapat diketahui model yang sesuai dalam modifikasi algoritme Bellman-Ford untuk mengoptimalisasi hasil dari pencarian rute terpendek.

\section{KESIMPULAN}

Modifikasi algoritme Bellman-Ford dapat mengoptimalkan pecarian rute terpendek berdasarkan
Tabel 8. Keterangan titik dan kriteria uji Bellman-Ford biasa

\begin{tabular}{|c|c|c|c|c|c|}
\hline Titik & C1 & $\mathrm{C} 2$ & C3 & $\mathrm{C4}$ & Jalan \\
\hline A-B & Stabil & 7 & 7 & 2,5 & Pengadegan Selatan \\
\hline B-C & Macet & 8,7 & 10 & 1,1 & Letjen MT Haryono \\
\hline C-E & $\begin{array}{l}\text { Sangat } \\
\text { Macet }\end{array}$ & 8 & 5 & 2,1 & DI Panjaitan \\
\hline A-D & $\begin{array}{l}\text { Sangat } \\
\text { Macet }\end{array}$ & 7 & 26 & 2,1 & Raya Kalibata \\
\hline D-E & Macet & 10 & 53 & 4,3 & $\begin{array}{l}\text { Mayjen Sutoyo, } \\
\text { Inspeksi Kalimalang }\end{array}$ \\
\hline $\mathrm{D}-\mathrm{C}$ & Macet & 12 & 20 & 1,6 & Dewi Sartika \\
\hline
\end{tabular}

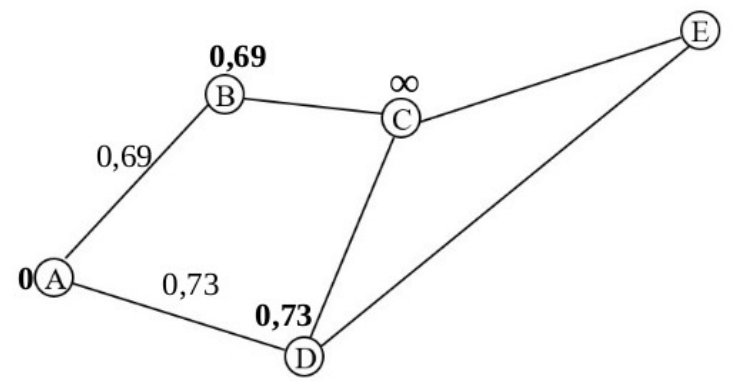

Gambar 6. Iterasi pertama graf Bellman-Ford tanpa modifikasi

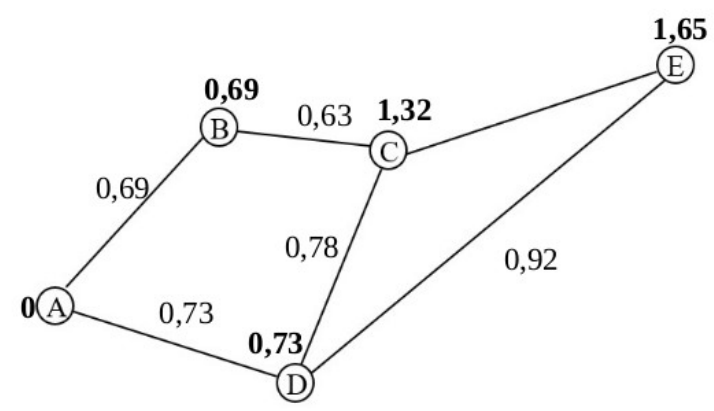

Gambar 7. Iterasi kedua graf Bellman-Ford tanpa modifikasi

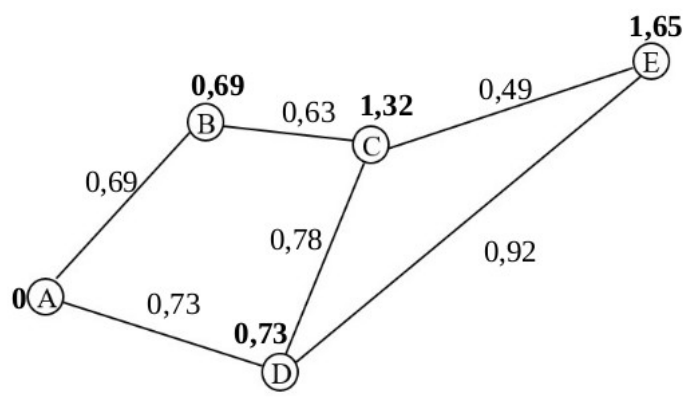

Gambar 8. Iterasi ketiga graf Bellman-Ford tanpa modifikasi

Tabel 9. Perbandingan kinerja algoritme

\begin{tabular}{lcc}
\hline \multicolumn{1}{c}{ Parameter } & BF & BF-TOPSIS \\
\hline Nilai rute & 1,65 & 1,44 \\
Jarak tempuh $(\mathrm{km})$ & 6,4 & 6,7 \\
Waktu tempuh (menit) & 79 & 84 \\
Kondisi jalan & macet & stabil \\
\hline
\end{tabular}


faktor-faktor kondisi jalan menggunakan penilaian TOPSIS, yaitu meliputi tingkat kepadatan jalan, lebar jalan, waktu, dan jarak tempuh serta dapat menentukan pilihan jalan alternatif jika antara dua titik memiliki beberapa pilihan jalan.

\section{UCAPAN TERIMA KASIH}

Ucapan terima kasih disampaikan kepada Universitas Trilogi atas pendanaan penelitian yang telah diberikan.

\section{Daftar Pustaka}

[1] A. Aji, S. H. Pramono, and M. A. Muslim,“ Optimasi Jalur Tercepat dengan Menggunakan Modifikasi Algoritma Bellman Ford,” Jurnal EECCIS, vol. 9, no. 2, pp. 168-172, 2015.

[2] P. M. Hasugian, "Analisa dan Implementasi Algoritma Bellman Ford dalam Menentukan Jalur Terpendek Pengantaran Barang Dalam Kota,” Jurnal Mantik Penusa, vol. 18, no. 2, pp. 118-123, 2015.

[3] M. Rofiq and R. F. Uzzy, "Penentuan Jalur Terpendek Menuju Cafe di Kota Malang Menggunakan Metode Bellman-Ford Dengan Location Based Service Berbasis Android,” Jurnal Ilmiah Teknologi dan Informasi Asia, vol. 8, no. 2, pp. 49-64, 2014.

[4] S. Hamdi, “Analisis Algoritma Dijktra dan Algoritma Bellman-Ford Sebagai Penentuan Jalur Terpendek Menuju Lokasi Kebakaran (Studi
Kasus : Kecamatan Praya Kota),” Energy, vol. 8, no. 1, pp. 26-32, 2018.

[5] J. O. Agung, T. Efendi, and H. Agung, “Analisis Perbandingan Algoritma Floyd-Warshall Dengan Algoritma Bellman-Ford Dalam Pencarian Rute Terpendek Menuju Museum di Jakarta,” Jurnal Sains dan Teknologi, vol. 5, no. 1, pp. 1-7, 2018.

[6] A. R. Wibowo and I. Soesanti, “Analisis Data Time Series Dan VCR Kepadatan Lalu Lintas (Studi Kasus : Jalan Adisucipto Depan Ambarukmo Plaza)," Elinvo (Electronics, Informatics, and Vocational Education), vol. 2, no. 2, pp. 131-137, 2015.

[7] A. Musthafa, H. Suyono, and M. Sarosa, "Perbandingan Kinerja Algoritma C.45 dan AHPTOPSIS Sebagai Pendukung Keputusan Proses Seleksi Penerima Beasiswa,” Jurnal EECCIS, vol. 9, no. 2, pp. 109-114, 2015.

[8] H. Wibisana and N. Utomo, "Pemetaan Kecepatan dan Kerapatan Lalu Lintas di Ruas Jalan Arteri Kota Surabaya,” Jurnal Teknik Sipil Maranatha, vol. 12, no. 2, pp. 99-181, 2016.

[9] E. S. Alhani, Komala Erwan, "Analisa Lalu Lintas Terhadap Kapasitas Jalan di Pinggiran Kota Pontianak (Kasus Jalan Sungai Raya Dalam)," Jurnal Mahasiswa Teknik Sipil Universitas Tanjungpura, vol. 4, no. 4, pp. 1-7, 2015.

[10] F. Anggraini and S. Mingparwoto, "Penerapan Metode Algoritma Bellman-Ford Dalam Aplikasi Pencarian Lokasi Perseroan Terbatas di PT Jakarta Industrial Estate Pulogadung (PT JIEP),” Jurnal Teknologi, vol. 7, no. 1, pp. 28-34, 2015. 